\title{
Removing Adult Overstory Trees Stimulates Growth and Transpiration of Conspecific Juvenile Trees
}

\author{
Georgianne W. Moore ${ }^{1}$ and M. Keith Owens ${ }^{2}$ \\ Authors are ${ }^{1}$ Assistant Professor, Department of Rangeland Ecology and Management, Texas A※M University, \\ College Station, TX 77843; and ${ }^{2}$ Professor, Texas Agricultural Experiment Station, Uvalde, TX 78801.
}

\begin{abstract}
During the last century, the density of Ashe juniper (Juniperus ashei Buchholz) has greatly increased in oak savannahs of central Texas. Recently, juniper removal has been advocated as a regional water conservation tool. In this study, we investigated whether juvenile trees released from an overstory canopy after clearing exhibited accelerated growth and water consumption. We compared leaf-level transpiration $\left(E_{1}\right)$ and carbon assimilation $\left(\mathrm{A}_{\text {net }}\right)$ rates among juvenile juniper under three different treatment scenarios: 1) in the open, 2) under an adult juniper canopy or 3) recently released by the removal of an adult juniper canopy. Released plants apparently grew faster and used more water than other juvenile trees; average $A_{\text {net }}$ of released plants was $94 \%-162 \%$ greater $(P<0.05)$ than those beneath an adult canopy and $22 \%-44 \%$ greater than open-grown plants. Furthermore, average $E_{1}$ of released plants was $22 \%-72 \%$ greater than those beneath an adult canopy and $13 \%-22 \%$ greater than open-grown plants. These differences persisted for at least two years after treatment. Rates of $\mathrm{A}_{\text {net }}$ were particularly elevated in released plants compared to other plants during periods of low water stress; whereas $E_{1}$ tended to be higher in released plants compared to other plants at all levels of water availability. Our evidence suggests released plants have better access to water, because at two out of three study sites, predawn leaf water potential $\left(\Psi_{\mathrm{p}}\right)$ was significantly more favorable for released plants than open-grown or under-canopy plants $(P<0.05)$. Although adult canopy removal temporarily reduced leaf area of juniper on a community level, and likely total water use, we demonstrated that released juveniles, at a minimum, partially compensated for the reduced overstory by increasing rates of water use and growth.
\end{abstract}

\section{Resumen}

Durante el siglo pasado la densidad de "Ashe juniper" (Juniperus ashei Buchholz) se ha incrementado grandemente en las savanas de encino de la región central de Texas. Recientemente la remoción de "Juniper" se ha enfocado como una herramienta de conservación de agua. En este estudio investigamos si los árboles juveniles liberados de una cobertura superior, después de un aclareo, muestran un crecimiento y consumo de agua acelerados. Comparamos las tasas de transpiración a nivel de hoja $\left(E_{1}\right)$ y la asimilación de carbón $\left(\mathrm{A}_{\text {net }}\right)$ entre arboles juveniles bajo tres tratamientos: 1) área abierta, 2) bajo una cobertura de árboles adultos y 3) recientemente liberados por la remoción de la cobertura de árboles adultos de "Juniper." Las plantas liberadas aparentemente crecieron mas rápido y usaron mas agua que otros árboles juveniles; el promedio de $\mathrm{A}_{\text {net }}$ de las plantas liberadas fue $94 \%-162 \%$ mayor $(\mathrm{P}<0.05)$ que aquellas debajo de la vcoberura de arboles adultos y $22 \%-44 \%$ mayor que la de las plantas creciendo en espacios abiertos. Además, el promedio de $E_{l}$ de las plantas liberadas fue $22 \%-72 \%$ mayor que el de las plantas bajo la cobertura de plantas adultas y $13 \%-22 \%$ mayor que las del espacio abierto. Estas diferencias persistieron por al menos dos a $4 \mathrm{~s}$ después de aplicar los tratamientos. Durante los periodos de estrés por poco agua, las tasa de $\mathrm{A}_{\text {net }}$ fueron particularmente elevadas en las plantas liberadas en comparación con las otras plantas; mientras que el $E_{1}$ tendio a ser mayor enlas plantas liberadas en comparación con las otras plantas en todos los niveles de disponibilidad de agua Nuestra evidencia sugiere que las plantas liberadas tienen un mejor acceso al agua, porque en dos de los tres sitios de estudio el poetncial de agua de la hoja predawn $\left(\Psi_{\mathrm{p}}\right)$ fue significativamente mas favorable para las plantas liberadas que para las plantas creciendo en espacios abiertos o bajo la copa de árboles $(P<0.05)$. Aunque la remoción de la copa de plantas adultas redujo temporalmente el área foliar del "Juniper" a nivel de comunidad y probablemente el uso total de agua, nosotros demostramos que las plantas juveniles liberadas, al menos, compensaron parcialmente la reducción de copa al incrementar las tasas de uso de agua y crecimiento.

Key Words: brush management, ecohydrology, Edwards plateau, Juniperus ashei, leaf carbon assimilation, savanna

\section{INTRODUCTION}

Juniper has increased in cover and relative abundance throughout the western United States, including the Great Basin

Research was funded in part by the USDA (95-38300-1693), Edwards Aquifer Authority, and the San Antonio Water Systems. Field site access was provided by the Annandale Ranch, Wayne Cheney Ranch, and the Texas Agricultural Experiment Station at Sonora.

Correspondence: Georgianne W. Moore, Rangeland Ecology and Management Dept, MS2126, Texas A\&M University, College Station, TX 77843. Email: gwmoore@tamu.edu

Manuscript received 15 December 2005; manuscript accepted 23 April 2006.
(Blackburn and Tueller 1970; Tausch et al. 1981; Miller and Rose 1999; Wall et al. 2001), northwest Texas (Ansley et al. 1995; Ueckert et al. 2001), and oak savannas in the Edwards Plateau region of central Texas (Archer 1994; Van Auken 2000). This expansion has been attributed in part to reduced fire frequency (Belsky 1996; Miller and Rose 1999; Van Auken 2000) and to livestock herbivory (Archer 1994; Belsky 1996; Miller and Rose 1999; Van Auken 2000). Vegetation shifts from grass to tree dominance impact a variety of ecosystem processes, including disturbance regimes, carbon and nutrient cycling, and soil stability (Schlesinger et al. 1990; Archer et al. 2001). 
In semi-arid rangeland of the southwestern United States, woody plant control has long been a method to reduce competition for resources and enhance growth of forage plants. Yet previous studies with juniper indicate success of such efforts depends on a variety of factors, including treatment application (Rasmussen and Wright 1989), climate (Wilcox 2002), species characteristics (Wilcox 2002), topography (Rasmussen and Wright 1989), and soil/geology (Wu et al. 2001; Wilcox 2002). Often woody dominance quickly re-establishes through resprouting (Ueckert et al. 2001), rapid seedling establishment or hastened growth rates of remaining juveniles (Owens and Schliesing 1995).

The Edwards Aquifer region is a vitally important water source for south Texas that supplies water for municipal and urban populations of over 1.7 million people, and also supplies agricultural irrigation water for approximately $660 \mathrm{~km}^{2}$. Water demands for municipal and agricultural purposes in the Edwards Aquifer region have escalated from $1.5 \times 10^{8} \mathrm{~m}^{3}$ of water in 1940 to a commitment of $6.8 \times 10^{8} \mathrm{~m}^{3}$ of water in 2005 (Gene Camargo, personal communication, January 2006). Concurrent with the demand increase, the dominant tree in the Edwards Plateau (Ashe juniper [Juniperus ashei Buchholz]) has increased in abundance. Concern has been raised that juniper may contribute to aquifer drawdown due to high year-round transpiration rates. Woody plant control may provide potential water savings to the region (Dugas and Mayeux 1991; Wu et al. 2001; Wilcox 2002; Wilcox et al. 2005). For woody plant management to successfully enhance groundwater recharge, the vegetation remaining after land clearing must use significantly less water than pretreatment vegetation. The magnitude and time frame over which this management effectively increases groundwater supply depends on the response of the remaining plant community.

In this paper, we focus on responses of Ashe juniper juveniles to overstory canopy removal. Juvenile junipers remaining on a site after adult overstory removal possess the potential to rapidly consume residual water resources because of reduced competition with adults. We must understand how juvenile juniper trees respond to overstory removal in order to target management strategies that provide for the most beneficial and long-lived results.

The objective of this study was to compare leaf-level carbon assimilation $\left(\mathrm{A}_{\mathrm{net}}\right)$ and transpiration $\left(E_{1}\right)$ rates of Ashe juniper juveniles under three treatment scenarios: 1) in open canopy interspaces (open), 2) shaded beneath an adult juniper canopy (canopy), and 3) released following mechanical removal of an adult juniper overstory canopy (released). The null hypothesis can be stated that $A_{\text {net }}$ and $E_{1}$ rates of released juvenile plants are no greater than open or shaded plants. Shaded plants, however, are expected to have lower rates of $\mathrm{A}_{\text {net }}$ (and perhaps $\left.E_{1}\right)$ than open-grown plants due to light limitations (Kozlowski et al. 1991). Furthermore, we predict higher $E_{1}$ (and perhaps $\mathrm{A}_{\text {net }}$ ) will occur in released juveniles relative to open-grown, at least temporarily after treatment. The logical framework for this hypothesis is as follows. Microsite conditions may be more ideal where an adult plant is (or was) located, either due to pre-existing factors attributable to the long-lived success of the adult (e.g. deeper soil with greater water-holding capacity) or due to factors created by the adult itself (e.g. deeper litter layer, more soil nutrients, greater soil water holding capacity). Conversely, if competition for water from adults is the primary limiting factor for growth and water uptake, then gas exchange of open-grown juveniles would be comparable to those juveniles whose overstory had been removed. Therefore our alternative hypothesis is that $A_{\text {net }}$ and $E_{1}$ rates are greatest in released plants, intermediate in open-grown plants, and least in shaded plants.

\section{METHODS}

The study was conducted at three sites located along a climatic gradient (Larkin and Bomar 1983) within the Edwards Aquifer region of Texas. The western most site was the Sonora Research Station (lat $30^{\circ} 15^{\prime} 57^{\prime \prime} \mathrm{N}$, long $100^{\circ} 33^{\prime} 55^{\prime \prime} \mathrm{W}$, elev. = $632 \mathrm{~m})$. Long-term average precipitation (1918-1988) was $609 \mathrm{~mm}$, with $409 \mathrm{~mm}$ falling during the growing season (Riddle et al. 1996). Soils on the Sonora study site are shallow $(<15 \mathrm{~cm})$ Tarrant stony clays over a fractured limestone bedrock. The second study site was on the Annandale Ranch (lat $29^{\circ} 29^{\prime} 20^{\prime \prime} \mathrm{N}$, long $99^{\circ} 44^{\prime} 17^{\prime \prime} \mathrm{W}$, elev. = $365 \mathrm{~m}$ ), approximately $117 \mathrm{~km}$ southeast of the Sonora site. Long-term precipitation at the Annandale site was $630 \mathrm{~mm}$ (19511990). Precipitation is bimodally distributed with early summer (May-June) and early autumn (September) receiving the most monthly precipitation, although high intensity storms from hurricanes make precipitation erratic. Soils on this site are in the Ector series (lithic calciustolls), about $15 \mathrm{~cm}$ deep consisting of $50 \%$ limestone fragments and $50 \%$ clay loam soil underlain by fractured limestone bedrock. The third study site, an additional $43 \mathrm{~km}$ to the east of the Annandale Ranch, was located on the Cheney Ranch (lat $29^{\circ} 25^{\prime} 08^{\prime \prime} \mathrm{N}$, long $99^{\circ} 18^{\prime} 22^{\prime \prime} \mathrm{W}$, elev. $=320 \mathrm{~m}$ ) in the Seco Creek drainage. Longterm precipitation records were not available for the ranch, but local records indicate $733 \mathrm{~mm}$ average annual precipitation (1990-1997). Soils on the Seco Creek site are in the Real series (typic caliustolls) where soils are less than $30 \mathrm{~cm}$ deep and consist of about $80 \%$ limestone fragments and $20 \%$ very gravelly clay loam. Rock outcrops are common. The Seco site was grazed by cattle at a low to moderate stocking rate (Wayne Cheney, personal communication, June 1996) but the other two sites were not grazed during the trial.

All three sites were dominated by a mixture of plateau live oak (Quercus virginiana var. fusiformis Mill.) and Ashe juniper. Mature juniper trees at Sonora were 3-4 m tall, at Annandale were 3-5 m tall, and at Seco Creek were 4-6 m tall. Other woody vegetation at all sites included Texas persimmon (Diospyros texana Scheele) and mountain laurel (Sophora secundiflora Ort.). Dominant grasses were common curley mesquite (Hilaria belangeri [Steud.] Nash), sideoats grama (Bouteloua curtipendula [Michx.] Torr.), and Wrights threeawn (Aristida purpurea var. wrightii [Nash] Allred). The Seco Creek site also had a patchy cover of little bluestem (Schizachyrium scoparium [Michx.] Nash).

At each site, 30 juvenile juniper trees were selected with 20 of the juveniles under the canopy of a mature juniper tree and 10 in the interspace area between mature trees. Of the 20 juveniles under a mature tree, 10 were randomly selected to have the mature tree removed. Consequently, 10 trees were assigned to each of the three treatments, open, canopy, and released. Juveniles had to be within the perimeter of the adult canopy to be "canopy." Interspace juveniles were considered "open" if located at least one canopy width away from a mature tree. A tree was considered a juvenile if it was $<1 \mathrm{~m}$ tall and 
there was no evidence of reproduction (Donovan and Ehleringer 1991). Juveniles were selected as paired plants with pairs being no greater than $2 \mathrm{~m}$ apart.

From each pair of trees, one was randomly selected for gas exchange measurements while the other was used for xylem water potential $\left(\Psi_{\mathrm{p}}\right)$ measurements, resulting in $\mathrm{n}=5$ for gas exchange measurements in each treatment. Removing leaf samples for leaf area determination of gas exchange measurements and axial stems for water potential samples would have removed too much leaf material from a single plant. A Scholander pressure chamber (Model 3000, Soil Moisture Equipment Corp, Goleta, CA) measured xylem water potential $\left(\Psi_{\mathrm{p}}\right)$ on axial stems during early morning hours.

Gas exchange, photosynthetically active radiation, and vapor pressure deficit $(\delta e)$ were sampled with an infrared gas analyzer (model LI6200, Licor, Inc, Lincoln, NE) closed path system. Approximately $4-12 \mathrm{~cm}^{2}$ of leaf area was enclosed in a 1/4 liter chamber for two sequential measurements. Each measurement was $<30$ seconds long and the first measurement was selected for analysis because it best approximated steady state conditions. Samples were taken on the northeast and southwest sides of the tree to account for canopy differences (Owens 1996). Samples were taken from the top third of the tree canopy. A measurement was made on the same leaf throughout the day at approximately 3-hour intervals, yielding 5 measurements on each tree for each sample period. After the first sample, the leaf was marked and then re-used for the remainder of the day. During winter the evening period was not sampled because of the short day length. After gas exchange measurements were completed for the day, enclosed leaf material was harvested for leaf area determination. Projected leaf area was measured following the methods described in Owens (1996). Measurements of gas exchange and $\Psi_{p}$ were repeated at each study site approximately every 60 days between 12 June 1996 and 17 February 1998, more frequently during the summer months, less frequently during the winter months. Because of the shallow rocky soils, surface soil moisture measurements were not feasible. Moreover, it is unlikely that surface soil water availability was as important as deeper sources (Jackson et al. 1999) in controlling leaf level responses.

Our primary objective was to compare leaf level gas exchange and $\Psi_{\mathrm{p}}$ among the three treatments, open, canopy, and released. Because the integrated effect of mature overstory tree removal was of primary interest, the first analysis was of data combined for all measurement days and all times of day. Because simultaneous measurements at all three sites were not feasible, observations among sites could be separated by as much as 14 days; hence statistical comparisons among sites were not part of the study design. Rather, results from each site are reported separately. Following a complete randomized design single factor analysis of variance (CRD), mean gas exchange and $\Psi_{\mathrm{p}}$ was compared among treatment groups using multiple comparisons based on the Fisher least significant difference procedure. Further analyses partitioned the results by time of day (morning, afternoon, and evening periods) and season (warm [May-September] and cool [November-March]) within each site and were tested using the CRD model described above to determine whether observed differences among treatments followed temporal trends. All tests were conducted using $P<0.05$ and means are reported \pm one standard error.

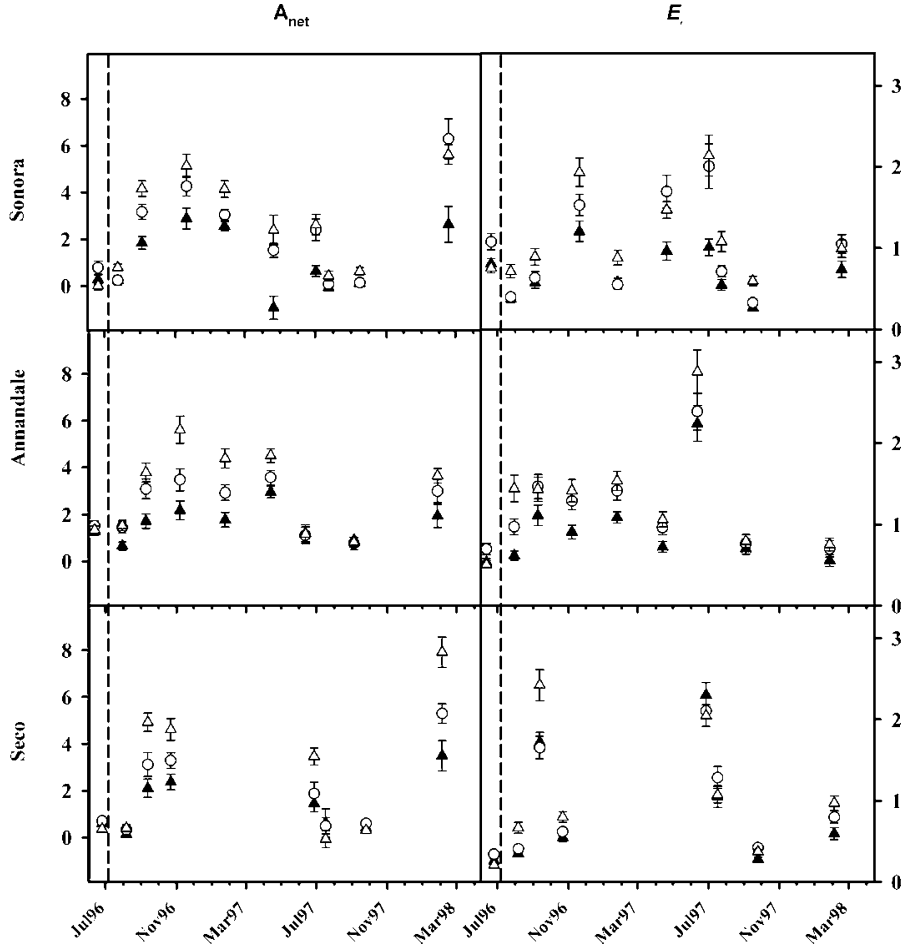

Figure 1. Average daily net photosynthesis $\left(A_{\text {net }}, \mu \mathrm{mol} \cdot \mathrm{m}^{-2} \cdot \mathrm{s}^{-1}\right)$ and leaf transpiration $\left(E_{1}, \mathrm{mmol} \cdot \mathrm{m}^{-2} \cdot \mathrm{s}^{-1}\right)$ by site and treatment (canopy $=$ black triangle; open $=$ white circle; released $=$ white triangle) for each measurement date. Error bars denote standard errors of daily means. Values left of the vertical dashed line were collected prior to treatment.

\section{RESULTS}

Although the three study sites are situated along a strong eastwest climatic gradient (Larkin and Bomar 1983), short-term precipitation differed little among sites during the study period. Total precipitation, beginning six months before treatment through termination of measurements (January 1996-February 1998), was 1243, 1306, and 1388 mm near Sonora, Annandale, and Seco study sites, respectively. Without two large rain events that occurred at the Sonora site in May $(113 \mathrm{~mm})$ and November $1996(70 \mathrm{~mm})$ precipitation was virtually equal at the three sites for the majority of the study.

The infrequent sampling intervals encompassed a large range of growing conditions, but did not demonstrate distinct seasonal trends in gas exchange (Fig. 1). The greatest mean values of $A_{\text {net }}$ were observed during winter sampling periods corresponding with cooler air temperatures. The greatest mean values of $E_{1}$ were observed in late June or early July, but $E_{1}$ likely reflected more day-to-day rather than seasonal climatic differences. Seasonal trends in $E_{1}$ varied widely among the three research sites (Fig. 1).

Following treatment, the $A_{\text {net }}$ of released plants frequently exceeded that of canopy or open-grown plants, averaging highest 8 of 9,6 of 8 , and 5 of 7 observation days at the Sonora, Annandale, and Seco sites, respectively (Fig. 1). Similarly, average $E_{1}$ of released plants also frequently exceeded that of canopy or open-grown plants, being highest 7 of 9,7 of 8 , and 4 of 7 observation days at the Sonora, Annandale, and Seco sites, respectively (Fig. 1). However, prior to treatment 


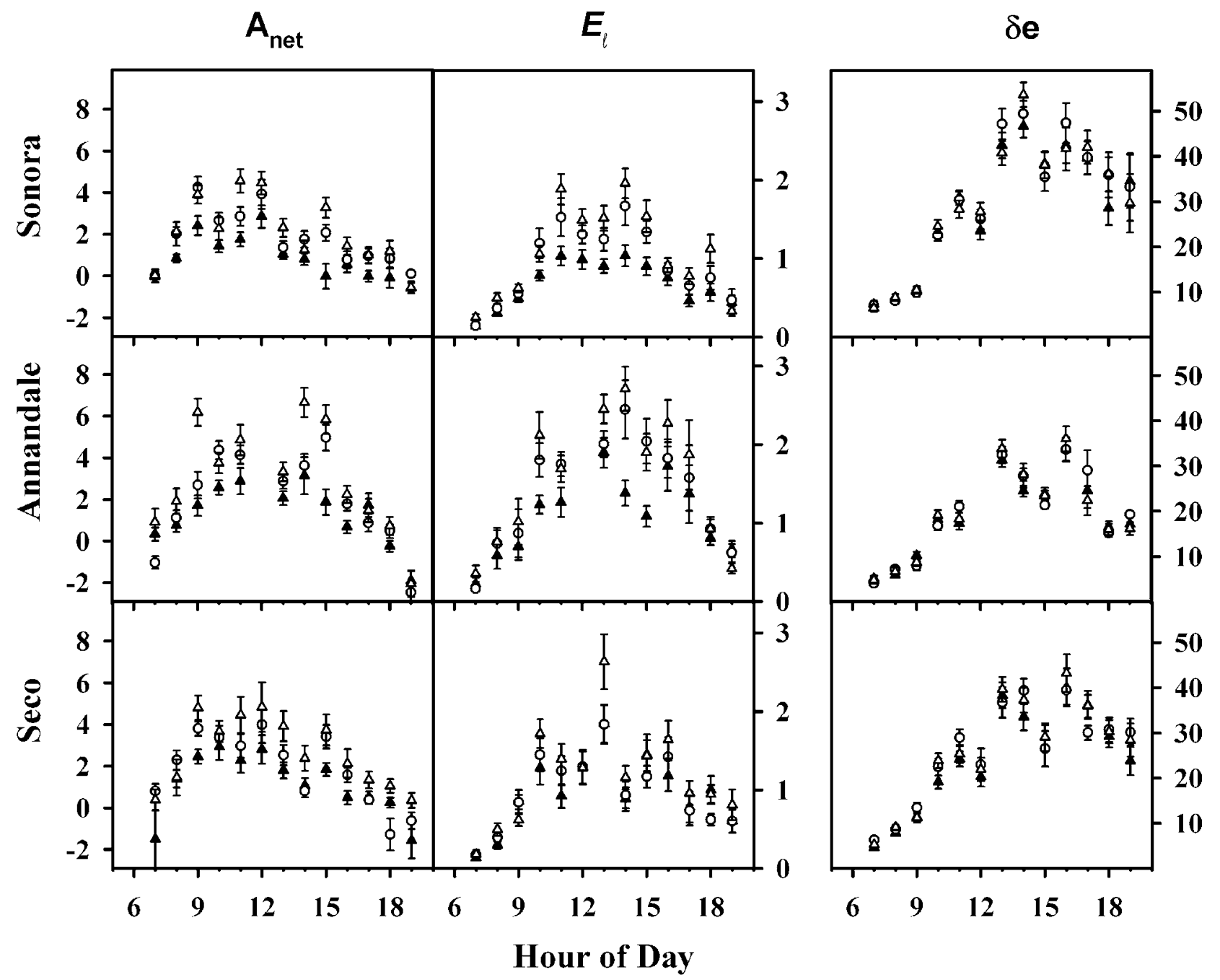

Figure 2. Average hourly net photosynthesis $\left(A_{\text {net }}, \mu \mathrm{mol} \cdot \mathrm{m}^{-2} \cdot \mathrm{s}^{-1}\right)$, leaf transpiration $\left(E_{1}, \mathrm{mmol} \cdot \mathrm{m}^{-2} \cdot \mathrm{s}^{-1}\right)$, and vapor pressure deficit $(\delta e, \mathrm{kPa})$ by site and treatment (canopy $=$ black triangle; open $=$ white circle; released $=$ white triangle). Error bars denote standard errors of hourly means.

in June 1996, differences in $A_{n e t}, E_{1}$, and $\Psi_{\mathrm{p}}$ did not differ between canopy plants and those designated to be "released." At Seco, $E_{1}$ was actually lower in released plants than canopy plants prior to the treatments; pretreatment means were $0.21 \pm$ 0.01 and $0.26 \pm 0.01 \mathrm{mmol} \cdot \mathrm{m}^{-2} \cdot \mathrm{s}^{-1}$ for released and canopy, respectively $(\mathrm{p}=0.03$, $\mathrm{t}$-test $)$.

Repeated sampling throughout the daylight hours demonstrated the diel trends of gas exchange and water use when all sample dates were combined (Fig. 2). Diel patterns indicate distinct differences among sites; the site with the highest and earliest peak of $\delta$ e (i.e. Sonora) had sharper afternoon declines in $A_{\text {net }}$ and $E_{1}$ (Fig. 2). On average, both $A_{\text {net }}$ and $E_{1}$ of released plants at all sites exceeded those of canopy or open plants during peak times of gas exchange.

Combining data from all measurement dates (Fig. 1) and times (Fig. 2) resulted in combined rates of $A_{\text {net }}$ and $E_{1}$ that were significantly greater at all sites per unit leaf area $(P<$ 0.05 ) in released plants than those grown under an adult canopy. Values for $A_{\text {net }}$ were also significantly greater in released plants than those grown in the open at the Seco site (Table 1). Average $A_{\text {net }}$ of released plants was $94 \%-162 \%$ greater than that of plants beneath an adult canopy and $22 \%-44 \%$ greater than open-grown plants. In the same individuals, average
$E_{1}$ of released plants was $22 \%-72 \%$ greater than that of plants beneath an adult canopy and $13 \%-22 \%$ greater than open-grown plants. At the Sonora and Annandale sites, $\Psi_{\mathrm{p}}$ was significantly more favorable for released plants than those grown in the open or under an adult canopy $(P<0.05$, Table 1). No differences in $\Psi_{\mathrm{p}}$ were detected at the Seco site because of high variability; standard errors were between 0.11 and 0.23 $\mathrm{MPa}$. The pattern among treatments appeared similar at all sites; compared to plants beneath the canopy, average $\Psi_{\mathrm{p}}$ was $0.14-0.60 \mathrm{MPa}$ higher in released plants and $0.05-0.21 \mathrm{MPa}$ lower in open-grown plants (Table 1).

The observed differences in $A_{\text {net }}$ and $E_{1}$ among treatments persisted for at least 21 months (Fig. 3). Net assimilation and $E_{1}$ of released plants usually contrasted more with those beneath the canopy than with juveniles in the open. Net assimilation remained between $40 \%$ and $80 \%$ greater in released plants than those beneath the canopy at all sites throughout the study. Net assimilation was also consistently greater in released than open-grown plants for the study duration (Fig. 3a). Similarly, compared to either canopy or open-grown plants, $E_{1}$ remained greater in released plants towards the end of the study; although some observations showed the opposite trend (Fig. 3b). Further, net assimilation was particularly elevated in 
Table 1. Mean (SE) values of net photosynthesis $\left(A_{\text {net }}, \mu \mathrm{mol} \cdot\right.$ $\left.\mathrm{m}^{-2} \cdot \mathrm{s}^{-1}\right)$, leaf transpiration $\left(E_{1}, \mathrm{mmol} \cdot \mathrm{m}^{-2} \cdot \mathrm{s}^{-1}\right)$, and leaf water potential $\left(\Psi_{\mathrm{p}}, \mathrm{MPa}\right)$ among three microsite treatments at three sites in the Edwards Plateau. Mean comparisons between treatments within a site are indicated by lower case letters; means within a site with the same letter do not differ (Fisher's LSD, $P<0.05){ }^{1}$

\begin{tabular}{clccc}
\hline \multirow{2}{*}{ Site } & Treatment & $\begin{array}{c}\mathrm{A}_{\text {net }} \\
\mu \mathrm{mol} \cdot \mathrm{m}^{-2} \cdot \mathrm{s}^{-1}\end{array}$ & $\begin{array}{c}E_{\mathrm{l}} \\
\mathrm{mmol} \cdot \mathrm{m}^{-2} \cdot \mathrm{s}^{-1}\end{array}$ & $\begin{array}{c}\Psi_{\mathrm{p}} \\
\mathrm{MPa}\end{array}$ \\
\hline Sonora & canopy & $1.06(0.21) \mathrm{a}$ & $0.70(0.06) \mathrm{a}$ & $-2.2(0.03) \mathrm{a}$ \\
& open & $2.28(0.28) \mathrm{b}$ & $0.99(0.09) \mathrm{b}$ & $-2.4(0.11) \mathrm{a}$ \\
& released & $2.77(0.16) \mathrm{b}$ & $1.20(0.07) \mathrm{b}$ & $-1.6(0.10) \mathrm{b}$ \\
\multirow{5}{*}{ Annandale } & canopy & $1.68(0.34) \mathrm{a}$ & $1.09(0.06) \mathrm{a}$ & $-1.0(0.02) \mathrm{a}$ \\
& open & $2.48(0.26) \mathrm{ab}$ & $1.34(0.13) \mathrm{ab}$ & $-1.1(0.03) \mathrm{a}$ \\
& released & $3.26(0.15) \mathrm{b}$ & $1.51(0.07) \mathrm{b}$ & $-0.9(0.02) \mathrm{b}$ \\
Sec0 & canopy & $1.43(0.23) \mathrm{a}$ & $1.01(0.09) \mathrm{a}$ & $-2.1(0.11) \mathrm{a}$ \\
& open & $2.02(0.16) \mathrm{a}$ & $1.05(0.07) \mathrm{ab}$ & $-2.3(0.14) \mathrm{a}$ \\
& released & $2.91(0.35) \mathrm{b}$ & $1.23(0.03) \mathrm{b}$ & $-2.0(0.23) \mathrm{a}$ \\
\hline
\end{tabular}

${ }^{1}$ No. of trees $=5$ for each site and treatment.

released plants when daily average $\Psi_{\mathrm{p}}$ was greater than -1 $\mathrm{MPa}$, compared to open-grown or plants beneath the canopy (Fig. 4).

\section{DISCUSSION}

After woody plant removal, environmental conditions change that may stimulate growth and transpiration of remnant juvenile Ashe juniper. As with any species, but especially drought-adapted species such as juniper, important tradeoffs exist between carbon gain and water loss. The differences in $\mathrm{A}_{\text {net }}$ and $E_{1}$ observed among juvenile Ashe juniper treatments (grown in the open; under an adult canopy; or released from an adult overstory) provide insights into the relative importance of light, water, and nutrients for leaf-level physiology in this species.

Juveniles growing beneath an adult canopy most likely had suppressed $A_{\text {net }}$ because of light limitations due to shading by adults. Average light levels of beneath-canopy plants were only about half as much as those growing in the open (average of $439 \pm 14$ vs. $625 \pm 20 \mu \mathrm{mol} \mathrm{m} \mathrm{m}^{-2} \mathrm{~s}^{-1}$ ). Net assimilation beneath the canopy was only half that of released plants, but $E_{1}$ was only $18 \%-42 \%$ lower (Table 1 ). Other woody plants, such as basin big sagebrush (Artemisia tridentata var. tridentata Nutt.), exhibited decreased root growth and nutrient acquisition under shaded conditions (Cui and Caldwell 1997). Thus, it is possible that the decreased $\mathrm{A}_{\text {net }}$ observed in the shaded canopy microsite resulted from reduced root growth. Another possible explanation is that juvenile trees growing beneath canopies compete with the adult overstory for limited available water. If so, the resulting drought stress may have induced stomatal closure. The $\Psi_{\mathrm{p}}$ measurements in this study did not support this explanation because there was no significant difference in average $\Psi_{\mathrm{p}}$ between canopy and open treatments (Table 1).

In contrast, it appears that local belowground factors might have contributed to the enhanced $A_{\text {net }}$ and $E_{1}$ in released plants, as indicated by treatment differences in $\Psi_{\mathrm{p}}$ at two out of three sites. For example, residual roots might serve as conduits for hydraulic redistribution of water to the rooting zone of juvenile

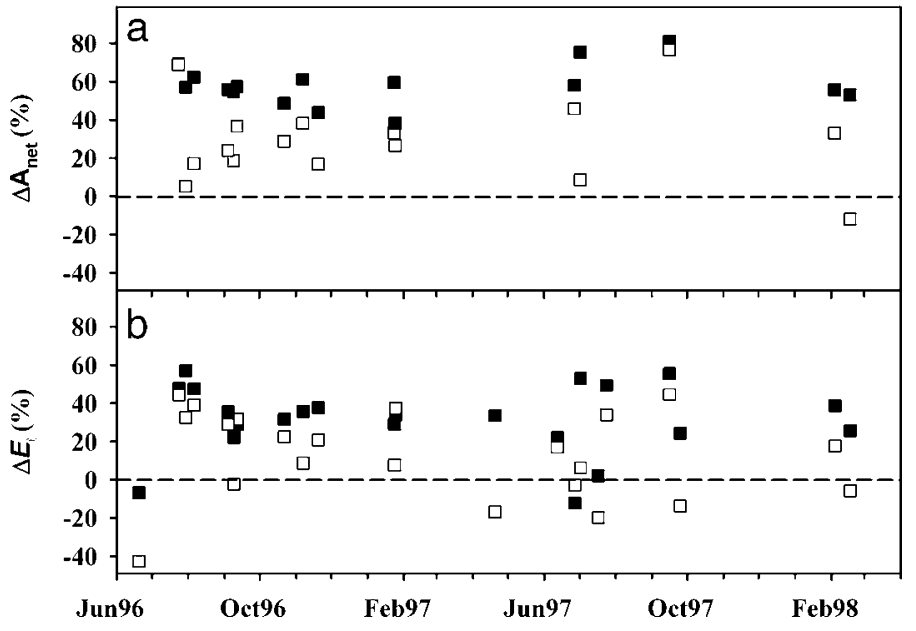

Figure 3. The percent difference (\%) in daily average net photosynthesis $\left(\Delta \mathrm{A}_{\text {net }}\right)$ and leaf transpiration $\left(\Delta E_{1}\right)$ between released and canopy (solid symbol) and between released and open (open symbol) plants. Values near zero indicate no net change in gas exchange due to treatments. Days with daily average $A_{\text {net }}<0$ were excluded.

plants between rain events (Leffler et al. 2005). Moreover, during rain events, preferential flow along residual roots (Martinez-Meza and Whitford 1996) may enhance soil moisture infiltration near released plants. It is reasonable to expect that locations shown to support the growth of an individual to adulthood may have advantageous local soil characteristics (e.g., microtopographic basin, deeper soils, or greater soil water holding capacity). Further, the adult itself provides abundant leaf litter to the juvenile growing beneath it, potentially enhancing nutrient availability and reducing soil evaporation. Previous studies indicated that Ashe juniper seedlings were more dense under canopies with litter than where litter was removed (Yager and Smeins 1999).

Accordingly, our results suggest that beneath-canopy juveniles are primed for rapid growth once the adult is removed.

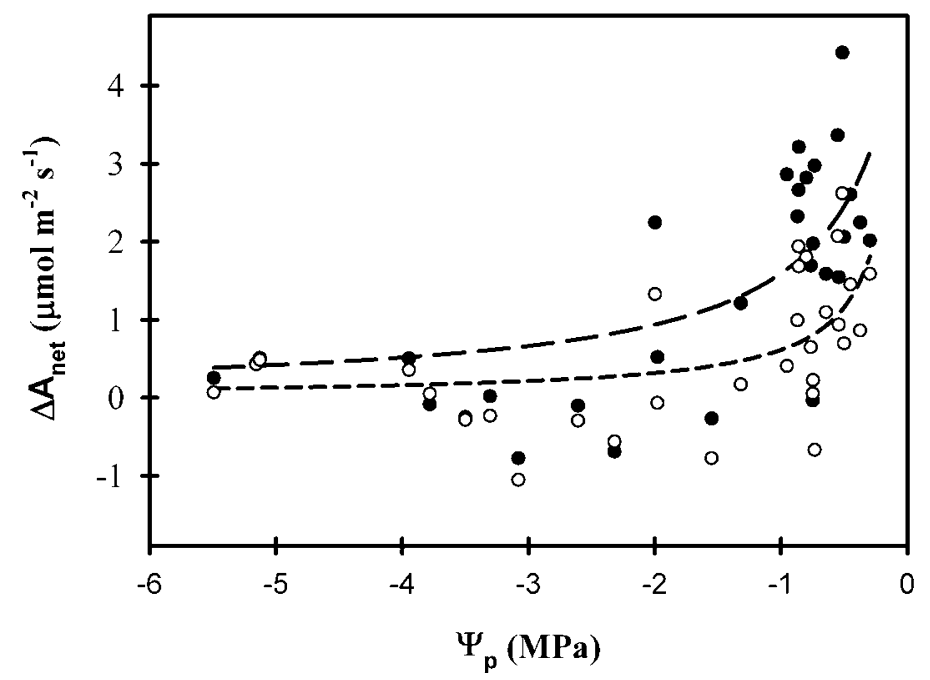

Figure 4. The difference in daily average photosynthetic rate $\left(\Delta A_{\text {net }}\right)$ between released and canopy (solid circle, long dash) and between released and open (open circle, short dash) compared to the daily average leaf water potential $\left(\Psi_{p}\right)$. 
Others have found higher soil moisture after shrub removal and that this water was used by seedlings. For example, Callaway et al. (1996) found that soil moisture after shrub removal was higher than soil moisture under shrubs or in the open. They also found that rates of $\mathrm{A}_{\text {net }}$ and $E_{1}$ in ponderosa pine (Pinus ponderosa Laws.) seedlings in shrub removal plots were greater than seedlings under shrubs or in the open. In another study, cutting western juniper (Juniperus occidentalis Hook.) resulted in significant increases in soil moisture and soil water potential, which, in turn, increased understory biomass (Bates et al. 2000). Xylem water potential values from this study (Table 1) also indicate that soil water conditions were significantly more favorable for released plants at two of the three sites, suggesting higher soil moisture following treatment.

The semiarid climate of south Texas is especially stressful for juniper growth and survival during the summer. The lowest rates of $A_{\text {net }}$ were observed in the warmest months (Fig. 1) when respiration costs to the plants were likely high. Seasonal patterns in $E_{1}$ were not apparent, suggesting the timing and magnitude of rain events more strongly influenced $E_{1}$ rates than did season.

\section{MANAGEMENT IMPLICATIONS}

In a region where woody plant removal is considered a potential means for enhancing water resources, this study provides compelling evidence that juvenile juniper plants remaining after treatment may partially offset any potential water gains. Further, physiological responses of released plants may jump start regrowth, potentially shortening the expected time interval between repeated woody plant management treatments. Control methods that effectively remove all juveniles, as well as adults, will more likely succeed in water conservation and require less frequent follow-up treatment of regrowth.

\section{ACKNOWLEDGMENTS}

We thank Rob Cosgriff for assistance with field data collection. Dr Dave Engle served as the Editor-in-Chief for this manuscript.

\section{LITERATURE CITED}

Ansley, R. J., W. E. Pinchak, and D. Ueckert. 1995. Changes in redberry juniper distribution in northwest Texas (1948 to 1982). Rangelands 17:49-53.

ARCHER, S. 1994. Woody plant encroachment into southwestern grasslands and savannas: rates, patterns, and proximate causes. In: M. Vavra, W. Laycock, and R. Pieper [EDS.]. Ecological implications of livestock herbivory in the West. Denver, CO: Society for Range Management. p 13-68.

Archer, S., T. W. Boutton, and K. A. Hibbard. 2001. Trees in grasslands: biogeochemical consequences of woody plant expansion. In: E.-D. Schultze, S. P. Harrison, M. Heimann, J. L. Holland, I. C. Prentice, and D. Schimel [EDS.]. Global biogeochemical cycles in the climate system. San Diego, CA: Academic Press, Inc. p 115-137.

Bates, J. D., R. F. Miller, and T. J. Svejcar. 2000. Understory dynamics in cut and uncut western juniper woodlands. Journal of Range Management 53:119-126.

BelSkY, A. J. 1996. Viewpoint: western juniper expansion: is it a threat to arid northwestern ecosystems? Journal of Range Management 49:53-59.

Blackburn, W. H., and P. T. Tueler. 1970. Pinyon and juniper invasion in black sagebrush communities in east-central Nevada. Ecology 51:841-848.
Callaway, R. M., E. H. Delucia, D. J. Moore, R. S. Nowak, and W. H. Schlesinger. 1996. Competition and facilitation: contrasting effects of Artemisia tridentata on desert vs. montane pines. Ecology 77:2130-2141.

CUI, M., AND M. M. Caldwell. 1997. Shading reduces exploitation of soil nitrate and phosphate by Agropyron desertorum and Artemesia tridentata from soils with patchy and uniform nutrient distributions. Oecologia 109:177-183.

Donovan, L. A., And J. R. Ehleringer. 1991. Ecophysiological differences among juvenile and reproductive plants of several woody species. Oecologia 86: 594-597.

Dugas, W. A., AND H. S. Mayeux. 1991. Evaporation from rangeland with and without honey mesquite. Journal of Range Management 44:161-170.

Jackson, R. B., L. A. Moore, W. A. Hoffmann, W. T. Pockman, and C. R. Linder. 1999. Ecosystem rooting depth determined with caves and DNA. Proceedings of the National Academy of Sciences 96:11387-11392.

Kozlowski, T. T., P. J. Kramer, and S. G. Pallardy. 1991. The physiological ecology of woody plants. San Diego, CA: Academic Press, Inc. 657 p.

Larkin, T. J., ANd G. W. Bomar. 1983. Climatic atlas of Texas. Austin, TX: Texas Department of Water Resources. $151 \mathrm{p}$.

Leffler, A. J., M. S. Peek, R. J. Ryel, C. Y. Ivans, and M. M. Caldwell. 2005. Hydraulic redistribution through the root systems of senesced plants. Ecology 86:633-642.

Martinez-Meza, E., and W. G. Whitford. 1996. Stemflow, throughfall and channelization of stemflow by roots in three Chihuahuan desert shrubs. Journal of Arid Environments 32:271-287.

MilleR, R. F., AND J. A. Rose. 1999. Fire history and western juniper encroachment in sage-brush steppe. Journal of Range Management 52:550-559.

Owens, M. K. 1996. The role of leaf and canopy-level gas exchange in the replacement of Quercus virginiana (Fagaceae) by Juniperus ashei (Cupressaceae) in semiarid savannas. American Journal of Botany 83:617-623.

Owens, M. K., AND T. G. Schliesing. 1995. Invasive potential of ashe juniper after mechanical disturbance. Journal of Range Management 48:503-507.

Rasmussen, G. A., AND H. A. WRIGHt. 1989. Succession of secondary shrubs on Ashe juniper communities after dozing and prescribed burning. Journal of Range Management 42:295-298.

Riddle, R. R., C. A. Taylor, M. M. Kothmann, and J. E. Huston. 1996. Volatile oil contents of ashe and redberry juniper and its relationship to preference by Angora and Spanish goats. Journal of Range Management 49:35-41.

Schlesinger, W. H., J. F. Reynolds, G. L. Cunningham, L. F. Huenneke, W. M. Jarrell, R. A. Virginia, ANd W. G. Whitford. 1990. Biological feedbacks in global desertification. Science 247:1043-1048.

Tausch, R. J., N. E. WeSt, And A. A. NABI. 1981. Tree age and dominance patterns in Great Basin pinyon-juniper woodlands. Journal of Range Management 34:259-264.

Ueckert, D., R. A. Phillips, J. L. Petersen, X. B. Wu, and D. F. Waldron. 2001. Redberry juniper canopy cover dynamics on western Texas rangelands. Journal of Range Management 54:603-610.

Van Auken, 0. W. 2000. Shrub invasions of North American semiarid grasslands. Annual Review of Ecology and Systematics 31:197-215.

Wall, T. G., R. F. Miller, and T. J. Svejcar. 2001. Juniper encroachment into aspen in the Northwest Great Basin. Journal of Range Management 54: 691-698.

WILCOX, B. P. 2002. Shrub control and streamflow on rangelands: a process based viewpoint. Journal of Range Management 55:318-326.

Wilcox, B. P., M. K. Owens, R. W. KNight, and R. Lyons. 2005. Do woody plants affect streamflow on semiarid karst rangelands? Ecological Applications 15:127-136.

Wu, X. B., E. J. Redeker, and T. L. Thurow. 2001. Vegetation and water yield dynamics in an Edwards Plateau watershed. Journal of Range Management 54:98-105.

Yager, L. Y., And F. E. Smeins. 1999. Ashe juniper (Juniperus ashei: Cupressaceae) canopy and litter effects on understory vegetation in a juniper-oak savanna. The Southwestern Naturalist 44:6-16. 